\title{
Modulation of In Vitro Monocyte Cytokine Responses to Leishmania donovani Interferon- $\gamma$ Prevents Parasite-induced Inhibition of Interleukin 1 Production and Primes Monocytes to Respond to Leishmania by Producing Both Tumor Necrosis Factor- $\alpha$ and Interleukin 1
}

\author{
Neil E. Reiner, ${ }^{\star \ddagger}$ Winnie Ng, " Christopher B. Wilson," W. Robert McMaster," and Sandra K. Burchett \\ Division of Infectious Diseases, Departments of ${ }^{*}$ Medicine, and Departments of ${ }^{\ddagger}$ Microbiology and "Medical Genetics, University of \\ British Columbia School of Medicine and Vancouver General Hospital, Vancouver British Columbia, Canada V5Z-1M9; \\ and Division of Infectious Diseases, ${ }^{8}$ Department of Pediatrics, University of Washington and \\ Children's Hospital and Medical Center, Seattle, Washington 98105
}

\begin{abstract}
Cytokines produced by mononuclear cells are important regulatory and effector molecules and evidence has been presented to support a role at least for tumor necrosis factor- $\alpha$ (TNF- $\alpha$ ) and interferon- $\gamma($ IFN- $\gamma)$ in host defense against Leishmania. In the present study, we examined the production of TNF- $\alpha$ and interleukin 1 (IL-1) by resting and IFN- $\gamma$-primed peripheral blood monocytes infected in vitro with Leishmania donovani. Monocytes produced neither IL-1 nor TNF- $\alpha$ during challenge with Leishmania. Cells preinfected with Leishmania synthesized normal amounts of TNF- $\alpha$, but had diminished production of $I L-1$ in response to stimulation with either $S$. aureus or lipopolysaccharide (LPS). The induction by $S$. aureus or LPS of IL-1 $\beta$ mRNA accummulation in infected cells was normal despite diminished intracellular or supernatant IL-1 protein and bioactivity. Thus, inhibition of IL-1 production by Leishmania most probably reflected diminished translation of IL-1 $\beta$ mRNA. Pretreatment of cells with IFN- $\gamma$ abrogated infection-induced inhibition of IL-1 production and primed cells for the production of both IL-1 and TNF- $\alpha$ upon subsequent exposure to Leishmania. These results indicate that $L$. donovani has evolved the capacity to infect mononuclear phagocytes, without stimulating the production of two potentially host-protective monokines. The ability of IFN- $\gamma$ to prime monocytes to produce TNF- $\alpha$ and IL-1 in response to infection with Leishmania and to prevent inhibition of IL-1 production may have implications for immunotherapy with this lymphokine. (J. Clin. Invest. 1990. 85:1914-1924.) Leishmania $\bullet$ monocytes $\bullet$ monokines $\bullet$ interferon- $\gamma$
\end{abstract}

\section{Introduction}

Cells of the mononuclear phagocyte series perform a large array of functions that are crucial to the integrity of the immune system and for host defense (1-3). In addition to strictly cellular functions such as antigen processing and presentation, antibody-dependent and antibody-independent cellular cytotoxicity and killing of both intracellular and extracellular mi-

Address reprint requests to Dr. Reiner, Department of Medicine, University of British Columbia, 910 West, 10th Avenue, Vancouver, BC V5Z 1M9, Canada.

Received for publication 1 August 1988 and in revised form 9 February 1990.

J. Clin. Invest.

(c) The American Society for Clinical Investigation, Inc.

$0021-9738 / 90 / 06 / 1914 / 11 \$ 2.00$

Volume 85, June 1990, 1914-1924 croorganisms, mononuclear phagocytes also produce and secrete a variety of cytokines that have potent, pleiotropic effects within the host (2). Important examples of the latter are interleukin 1 (IL-1) and tumor necrosis factor- $\alpha$ (TNF- $\alpha),{ }^{1}$ two cytokines which mediate a large and frequently overlapping repertoire of biological activities (4-8). In particular, IL-1 and TNF- $\alpha$ have been shown to be important elements in the host response to microbial invasion. For example, both IL-1 and TNF- $\alpha$ are produced in response to a variety of microbes and microbial products $(4,6)$ and in turn these cytokines have been shown to mediate antimicrobial activities both in vitro and in vivo (9-12).

Paradoxically, in spite of the prominent role of mononuclear phagocytes in host defense, a large number of diverse microorganisms have evolved the capacity to establish a state of intracellular parasitism within these cells. This suggests the possibility that in order to insure their own survival, these organisms may use strategies designed to either evade or subvert the regulatory or effector functions of their target cells. Protozoa of the genus Leishmania are an example of a group of organisms that have adapted remarkably well in respect to their ability to infect, propagate and persist within mononuclear phagocytes $(13,14)$. Given the pivotal roles of mononuclear phagocytes and of their cytokine products in mammalian homeostasis, it is important to understand how these functions may be perturbed during chronic intracellular infection. Moreover, with respect to Leishmania in particular, understanding how cytokine production is modulated in infected mononuclear phagocytes may be of fundamental importance to the immunobiology of the leishmaniases. Support for this concept derives from recent findings that demonstrated a protective role for TNF- $\alpha$ in experimental leishmaniasis (15) and from studies in which interferon- $\gamma$ (IFN- $\gamma$ ), a lymphokine that potentiates monocyte cytokine production (16-19), was shown to have therapeutic efficacy in human visceral leishmaniasis (20). Based upon these considerations, in the present study the modulation of IL-1 and TNF- $\alpha$ production by human monocytes during infection with Leishmania donovani (the causative agent of visceral leishmaniasis in the Old World) was examined. The question of whether IFN- $\gamma$ could modulate human monocyte responses to $L$. donovani for the production of TNF- $\alpha$ and IL-1 was also studied.

\section{Methods}

Leishmania and leismania lysate. Amastigotes of the Sudan strain $2 \mathrm{~S}$ of $L$. donovani used in this study were isolated from spleens of male

1. Abbreviations used in this paper: TNF, tumor necrosis factor. 
Syrian hamsters as described in detail previously (21). For use in some experiments, a soluble parasite lysate was prepared by suspending amastigotes in calcium- and magnesium-free Hanks' balanced salt solution and subjecting the suspension to six freeze $\left(-70^{\circ} \mathrm{C}\right)$ /thaw cycles. The suspension was then centrifuged at $12,500 \mathrm{~g}$ for $20 \mathrm{~min}$, and the supernatant was recovered, filter-sterilized, and adjusted to $1 \mathrm{mg} / \mathrm{ml}$ after protein determination by protein assay (Bio-Rad Laboratories, Richmond, CA).

Reagents and chemicals. RPMI 1640 and Dulbecco's modified Eagle's medium (DME, 4,500 mg/liter glucose) were prepared in the media preparation facility at the Terry Fox Laboratory of the Cancer Control Agency of British Columbia, and were supplemented with L-glutamine $(2 \mathrm{mM}), 2$-mercaptoethanol $\left(5 \times 10^{-5} \mathrm{M}\right)$, penicillin (100 $\mathrm{U} / \mathrm{ml}$ ), and streptomycin $(100 \mu \mathrm{g} / \mathrm{ml})$. In addition, DME was also supplemented with sodium pyruvate $(0.01 \mathrm{mM})$, Hepes $(10 \mathrm{mM})$, $\mathrm{L}$-arginine- $\mathrm{HCl}(1.48 \mathrm{mM})$, folic acid $(0.01 \mathrm{mM})$, and asparagine $(0.27$ mM). Hanks' balanced salt solution (HBSS), also prepared at the Terry Fox Laboratory, was supplemented with penicillin and streptomycin and Hepes $(10 \mathrm{mM})$ and adjusted to $\mathrm{pH} 7.4$ with $7.5 \%$ sodium bicarbonate. Histopaque (no. 1077) and lipopolysaccharide (LPS) (L-3129, Escherichia coli 0127:B8, lot no. 3123-25, B2F-4012) were from Sigma Chemical Co., St. Louis, MO. Fixed $S$. aureus cells of the Cowan I strain were from Calbiochem-Behring Corp., La Jolla, CA, as Pansorbin (no. 507858) as a $10 \%$ (wt/vol) solution in PBS. Methyl-tritiated thymidine was from Amersham, Oakville, Ontario with sp act $5 \mathrm{Ci}$ / mmol. Recombinant human IFN- $\gamma$ (lot no. K9079A, sp act $2.7 \times 10^{7}$ $\mathrm{U} / \mathrm{mg}$ ), recombinant human TNF- $\alpha$ (sp act $5 \times 10^{7} \mathrm{U} / \mathrm{mg}$ ), and the cDNA probes for human IL-1 $\beta$ (22) and human TNF- $\alpha$ (23) were generous gifts from Genentech Inc., South San Francisco, CA.

Cell preparation and culture. Peripheral blood mononuclear cells were isolated from buffy coats (obtained from normal human volunteers by the British Columbia and Yukon Division of the Canadian Red Cross) by centrifugation ( $800 \mathrm{~g}$ for $15 \mathrm{~min}$ ) over Histopaque. After three washes in HBSS, the cells were resuspended in RPMI 1640 with $10 \%$ human serum at $1 \times 10^{7}$ viable cells per $\mathrm{ml}$ and dispensed into $150-\mathrm{cm}^{2}$ tissue culture flasks $(20 \mathrm{ml}$ per flask for the preparation of cellular RNA) and incubated at $37^{\circ} \mathrm{C}$ in a $5 \% \mathrm{CO}_{2} / 95 \%$ air, humidified atmosphere for $45 \mathrm{~min}$. Nonadherent cells were removed by vigorous washing with divalent cation-free $\mathrm{HBSS}\left(37^{\circ} \mathrm{C}\right)$ and the flasks were replenished with RPMI 1640 supplemented with $20 \%$ fresh human serum for culture with or without the addition of various stimuli. Adherent monolayers prepared in this manner were $89 \pm 5 \%$ monocytes by morphologic and phagocytic criteria as determined by microscopic examination of Diff-Quik (B4132-1, CanLab, Vancouver, BC) stained preparations.

Monocyte supernatants for IL-1 and for TNF- $\alpha$ assays were generated by culturing $1 \times 10^{6}$ peripheral blood mononuclear cells per chamber of eight-chamber Lab-Tek chamber slides (no. 4808, Miles Scientific, Inc., Naperville, IL) in DME/10\% heat-inactivated fetal bovine serum (FBS) (lot 1111646, Hyclone Laboratories, Logan, Utah) for $60 \mathrm{~min}$ at $37^{\circ} \mathrm{C}$ in $5 \% \mathrm{CO}_{2} / 95 \%$ air. Nonadherent cells were removed by washing as above for flasks, and the chambers were replenished with DME 10\% FBS with or without stimulants. After overnight incubation (12-16 h), cell-free supernatants were collected and either assayed immediately or stored at $-70^{\circ} \mathrm{C}$. Monolayers prepared in this manner were $86 \pm 5 \%$ monocytes by both morphologic and phagocytic criteria as described above for flask cultures.

IL-1 assay. IL-1 activity in monocyte supernatants was assayed by the induction of $\left[{ }^{3} \mathrm{H}\right]$ thymidine incorporation into D10.G4.1 cells in the presence of a suboptimal concentration of concanavalin A $(0.625$ $\mu \mathrm{g} / \mathrm{ml}$, no. 234567, Calbiochem-Behring Corp.), (24). One unit of IL-1 activity was defined as that which stimulated $50 \%$ of maximal $\left[{ }^{3} \mathrm{H}\right]-$ thymidine incorporation by D10.G4.1 cells. Results from individual experiments were normalized against a standard preparation of IL-1 produced from normal human monocytes stimulated with $S$. aureus as described (25). As used under the experimental conditions of this study, the D10.G4.1 assay was shown to be specific for IL-1. This was demonstrated by neutralization of monocyte supernatants by rabbit polyclonal antisera specific for IL- $1 \alpha$ or IL- $1 \beta$ generously provided by Dr. Kenneth H. Grabstein of Immunex Corporation, Seattle, WA. Under the experimental conditions of this study, $>95 \%$ of the IL-1 activity detected in monocyte supernatants was neutralized by treatment with the anti-IL-1 $\beta$ serum. In selected experiments, the content of immunoreactive IL- $1 \beta$ in monocyte supernatants was determined by ELISA using an immunoassay kit (03-0096, Cistron Biotechnology, Pinebrook, NJ). The sensitivity of this assay system is $20 \mathrm{pg} / \mathrm{ml}$ and there is no cross-reactivity with IL-1 $\alpha$ or TNF.

Assay for $T N F-\alpha$. Immunoreactive TNF- $\alpha$ was measured by ELISA using a rabbit antibody to recombinant human TNF- $\alpha$ as the capture antibody and horseradish peroxidase conjugated mouse monoclonal anti-recombinant human TNF- $\alpha$ as the second antibody. Both antibodies were generously supplied by Genentech, Inc. The standard curve for detection of recombinant TNF- $\alpha$ was linear in the range of $25-1,000 \mathrm{pg} / \mathrm{ml}$.

Northern blot analyses. Total RNA was isolated from cells as described by Chirgwin et al. (26) using cesium chloride gradients. RNA was denatured and size separated on agarose formaldehyde gels as described (27) and transferred to nylon membranes (Hybond-N, Amersham). Blots were prehybridized, hybridized and washed following the manufacturer's protocol. IL- $1 \beta$ and TNF- $\alpha$ mRNAs were detected using human cDNA probes generously provided respectively by Dr. Patrick Gray (22) and Dr. Dianne Pennica (23) of Genentech Inc. DNA was oligolabeled with [ $\left.{ }^{32} \mathrm{P}\right] \mathrm{dCTP}$ using random primers as described (28).

Statistical analysis. Except where otherwise stated, the results shown are representative data from a minimum of three similar or identical experiments which yielded comparable results. Unless otherwise indicated, differences between experimental groups were examined using Student's $t$ test for independent means.

\section{Results}

Human monocyte IL-1 production during infection with Leishmania. Supernatants of freshly isolated, normal peripheral blood monocytes infected with $L$. donovani for $\sim 12 \mathrm{~h}$ showed no increase in IL-1 content when compared to control unstimulated cells (Fig. 1). In contrast, cells stimulated with heat-inactivated $S$. aureus or with LPS, released large amounts of IL-1 activity into their supernatants. The absence of increased IL-1 activity in the supernatants of leishmania-infected cultures appeared to be related to the failure of monocytes to accummulate IL-1 mRNA in response to infection (Fig. 2). Northern analysis showed that cells stimulated with $S$. aureus or with LPS for $\sim 12 \mathrm{~h}$ accummulated readily detectable amounts of IL-1 $\beta$ mRNA, whereas Leishmania-infected cells, like unstimulated cells, did not.

Inhibition of monocyte IL-1 production by leishmania infection. To examine whether monocytes infected with $L$. donovani could respond to a second stimulus for the production of IL-1, cells were infected with Leishmania for $4 \mathrm{~h}$ and then secondarily stimulated with either $S$. aureus or with LPS. Supernatants were collected $\sim 12 \mathrm{~h}$ after the addition of secondary stimuli and were assayed for IL-1 activity. The results shown in Fig. 1 demonstrate that supernatants of cells preinfected with Leishmania and secondarily stimulated with either $S$. aureus or with LPS contained significantly reduced IL-1 content when compared to supernatants of noninfected cells. This result was not likely to be related to suppressive factors in monocyte-conditioned media since, as shown in Table I, exactly parallel results were obtained when supernatants (derived from cells identically treated in separate experiments) were assayed for immunoreactive IL-1 $\beta$ by ELISA. 


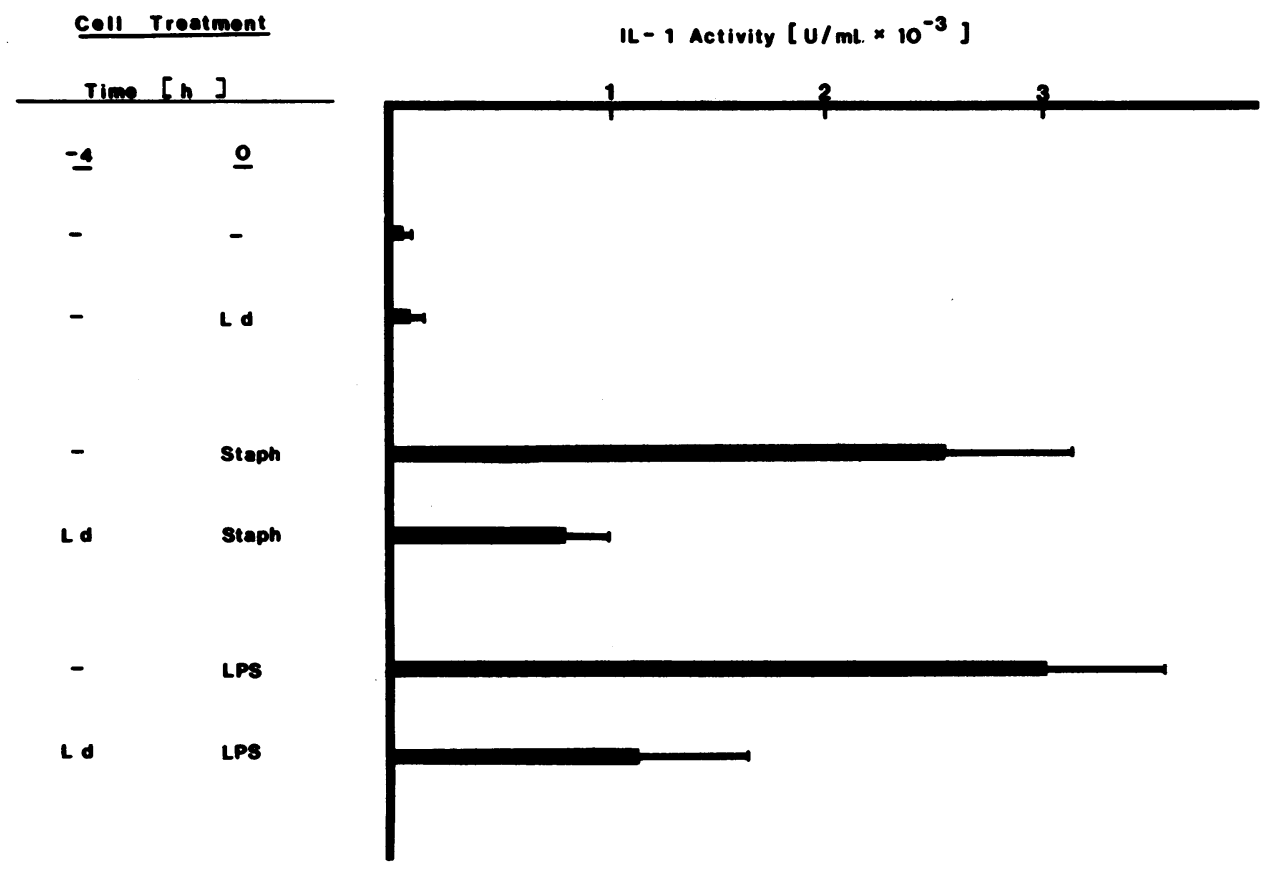

Figure 1. Human monocytes preinfected with $L$. donovani have suppressed IL-1 responses to $S$. aureus and LPS. Monolayers of freshly isolated human monocytes ( $>90 \%$ pure by morphologic and phagocytic criteria) were either untreated or exposed to amastigotes of Leishmania at a parasite/cell ratio of 10:1 (ultimate infection rate was $77 \%$ with 7 amastigotes per cell). $4 \mathrm{~h}$ later the monolayers were challenged with $S$. aureus $(0.005 \%$ as Pansorbin fixed $S$. aureus), LPS (1 $\mu \mathrm{g} / \mathrm{ml}$ ) or nil. Approximately $16 \mathrm{~h}$ later cell-free supernatants were harvested and assayed for IL-1 activity using D10.G4.1 cells. The results shown are from one of three identical experiments which yielded similar results, and represent the mean $\pm S D$ of triplicate determinations for each experimental group. The differences between $S$. aureus vs. Leishmania-S. aureus and LPS vs. Leishmania-LPS were significant at the $2 \%$ and $2.5 \%$ levels, respectively.
Reduced IL-1 content of supernatants derived from cells preinfected with Leishmania and secondarily stimulated with either $S$. aureus or with LPS was not related to altered kinetics of IL-1 release. Thus, as shown in Fig. 3, irrespective of the duration of incubation of Leishmania-infected cells with LPS, in comparison to LPS treated control cells, supernatants of infected monocytes had decreased IL-1 activity. In addition, reduced IL-1 content of supernatants derived from infected cells was shown (Table II) not to be related to intracellular accumulation of cytokine.
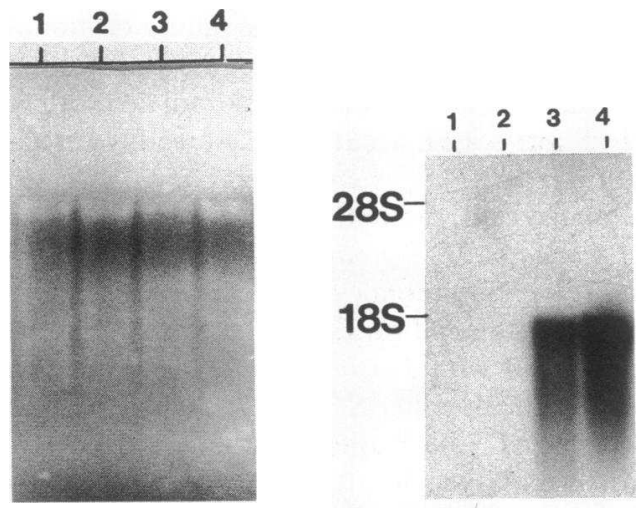

Figure 2. Northern blot analysis of IL-1 $\beta$ mRNA in human monocytes. Monolayers of freshly isolated monocytes treated as indicated below for $\sim 16 \mathrm{~h}$ were washed and lysed in guanidium isothiocyanate. Total cytoplasmic RNA, $5 \mu \mathrm{g}$, was fractionated on a $1.2 \%$ agarose formaldehyde gel and transferred to Hybond- $\mathrm{N}$ and hybridized with ${ }^{32}$ P-labeled cDNA insert of pHu IL-1 $\beta$ (right). Lane 1 , unstimulated monocytes; lane 2, Leishmania-infected monocytes; lane 3 , monocytes stimulated with $S$. aureus; lane 4, monocytes treated with LPS $(1 \mu \mathrm{g} / \mathrm{ml})$. (Left) Gel stained with acridine orange.
Additional experiments were carried out to determine whether inhibition of IL-1 production by Leishmania required infection with intact organisms. To examine this question, $4 \mathrm{~h}$ before stimulation with $S$. aureus, cells were either infected with Leishmania or treated with a soluble parasite lysate (prepared as described in Methods). As shown in Table III, cells preinfected with Leishmania had significantly decreased responses to $S$. aureus for IL-1 production. In contrast, in two of three experiments, pretreatment of cells with the parasite lysate $(10 \mu \mathrm{g} / \mathrm{ml})$ did not significantly affect the IL-1 response to

Table I. Content of Immunoreactive IL-1 $\beta$ in Supernatants of Monocytes Infected with $L$. donovani and Secondarily Treated with Either S. aureus or LPS

\begin{tabular}{|c|c|c|}
\hline \multirow[b]{2}{*}{ Cell treatment } & \multicolumn{2}{|c|}{$\begin{array}{l}\text { Immunoreactive IL-1 } \beta \\
\text { Experiment No. }\end{array}$} \\
\hline & 1 & 2 \\
\hline & \multicolumn{2}{|c|}{$n g / m l$} \\
\hline Nil & $<40^{*}$ & $<40$ \\
\hline S. aureus & 7,920 & 6,016 \\
\hline Leishmania and $S$. aureus & 2,144 & 1,424 \\
\hline LPS & 17,504 & 25,696 \\
\hline Leishmania and LPS & 6,240 & 8,960 \\
\hline
\end{tabular}

Monolayers of human monocytes were prepared and treated as described in the legend to Fig. 1. Cells treated with Leishmania were $\sim 70-80 \%$ infected with an average of three amastigotes per cell. 16 $h$ after the addition of stimuli, cell-free supernatants were collected and assayed for IL- $1 \beta$ by ELISA.

* Average of duplicate measurements for each treatment group. 


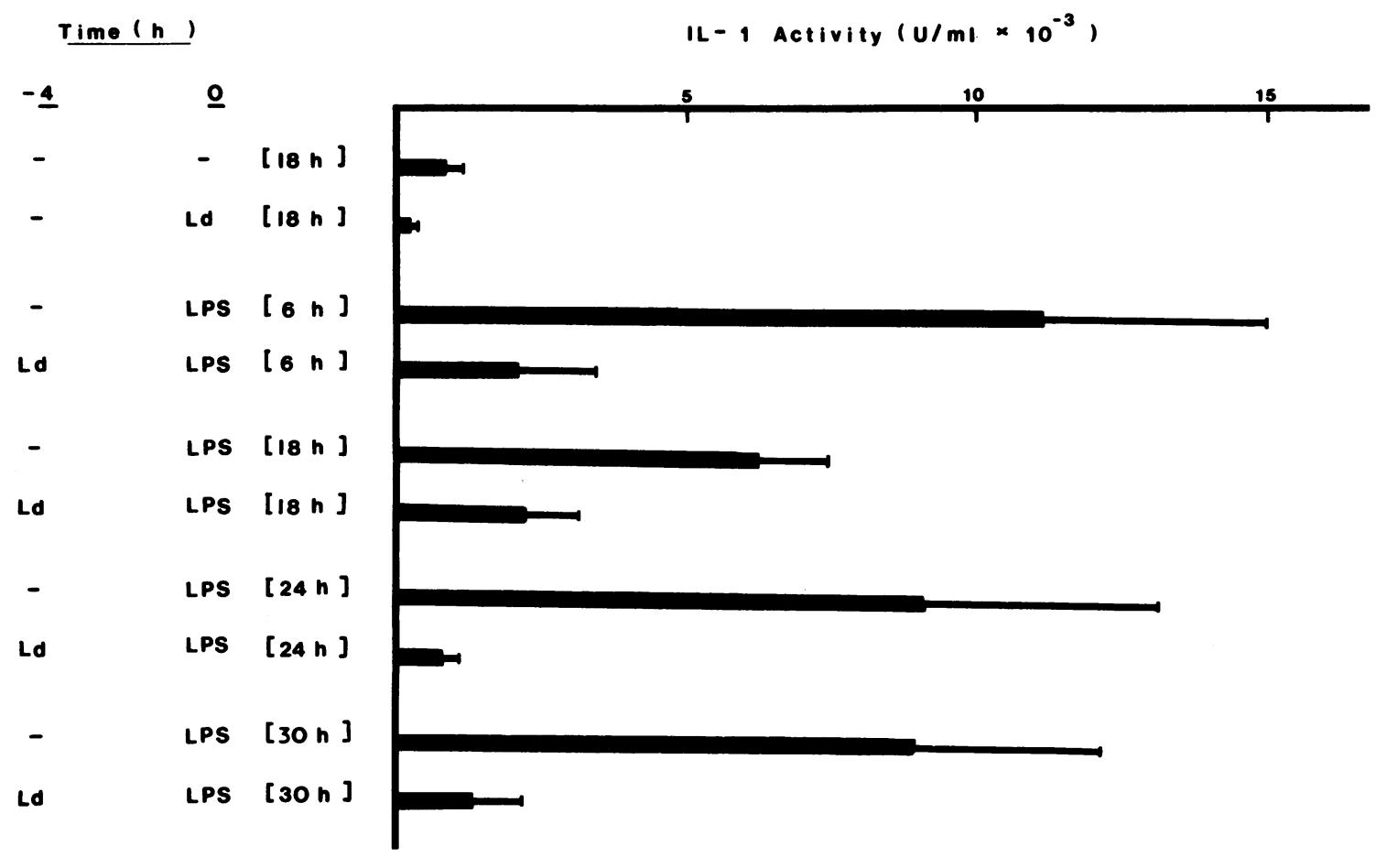

Figure 3. Kinetics of IL-1 release into supernatants of monocytes preinfected with Leishmania. Cells were prepared and treated as described in the legend to Fig. 1. After the indicated duration of exposure to LPS $(1 \mu \mathrm{g} / \mathrm{ml})$ supernatants were collected and assayed for IL-1 content using the D10.G4.1 cells. The results shown are from one of two identical experiments which yielded similar results, and represent the mean \pm SD of triplicate determinations for each experimental group. The differences between LPS vs. Leishmania-LPS at all time points were significant at $\leq$ the $5 \%$ level.

Table II. Supernatant and Intracellular IL-1 Bioactivities Derived from Monocytes Infected with $L$. donovani and Secondarily Treated with Either S. aureus or LPS

\begin{tabular}{|c|c|c|}
\hline \multirow[b]{3}{*}{ Cell treatment } & \multicolumn{2}{|c|}{$\begin{array}{l}\text { IL-1 bioactivity } \\
\text { Experiment No. }\end{array}$} \\
\hline & 1 & 2 \\
\hline & Supernatant/intracellular & Supernatant/intracellular \\
\hline & \multicolumn{2}{|c|}{$U / m l$} \\
\hline Nil & $23 \pm 15 / 3 \pm 2^{*}$ & $22 \pm 19 / 165 \pm 62$ \\
\hline Leishmania & $19 \pm 15 / 6 \pm 5$ & nil/199 \pm 109 \\
\hline S. aureus & $1524 \pm 317 / 104 \pm 17^{\ddagger}$ & $3355 \pm 1138 / 73 \pm 90^{\ddagger}$ \\
\hline \multicolumn{3}{|c|}{ Leishmania and } \\
\hline S. aureus & $175 \pm 97 / 122 \pm 30$ & $37 \pm 27 / 122 \pm 876$ \\
\hline LPS & $740 \pm 138 / 165 \pm 8^{\ddagger}$ & $2944 \pm 1318 / 130 \pm 74^{\ddagger}$ \\
\hline \multicolumn{3}{|c|}{ Leishmania and } \\
\hline LPS & $247 \pm 135 / 156 \pm 38$ & $110 \pm 93 / 30 \pm 5.2$ \\
\hline
\end{tabular}

Monolayers of human monocytes were prepared as described in the legend to Fig. 1 using 96-well, flat-bottom tissue culture plates and were either untreated or infected with $L$. donovani at a parasite/cell ratio of 10:1. $4 \mathrm{~h}$ later cells were either untreated or treated with LPS of $S$. aureus. $16 \mathrm{~h}$ after the addition of stimuli, cell-free supernatants and cell lysates were collected as described previously (25) from all treatment groups and assayed for IL-1 activity using D10.G4.1 cells. * Mean \pm SD of triplicate determinations for each experimental group.

* The differences in IL-1 activities in supernatants of cells treated with $S$. aureus vs. Leishmania-S. aureus and LPS vs. LeishmaniaLPS were significant at $\leq$ the $2.5 \%$ level.
$S$. aureus. In fact, in one experiment pretreatment with the lysate actually augmented the IL-1 response to $S$. aureus. These findings indicated that inhibition of IL-1 production by Leishmania required infection with intact organisms.

To analyse further, the mechanism(s) of inhibition of IL-1 production by Leishmania, cells were treated exactly as described in Fig. 1, and after 11-12 h of incubation with secondary stimuli, total RNA was isolated and hybridized with a cDNA probe for IL-1 $\beta$. As shown in Fig. 4, in these experiments cells treated with $S$. aureus (lane 3) or with LPS (lane 2) alone accummulated significant amounts of IL- $1 \beta$ mRNA. Of interest, monocytes preinfected with Leishmania and secondarily stimulated with LPS accummulated a level of IL- $1 \beta$ mRNA equal to that detected in cells stimulated with LPS alone (compare lanes 2 and 4 ), even though there was a significant reduction in the amount of IL-1 detected in the corresponding supernatants. In contrast, in the experiment shown here, monocytes preinfected with $L$. donovani and secondarily stimulated with $S$. aureus (lane 5) had no detectable IL-1 $\beta$ mRNA. A result identical to this was also obtained in a second experiment involving cells from another donor (data not shown). Inhibition of $S$. aureus-induced IL-1 $\beta$ mRNA accummulation in Leishmania-infected cells was not, however, a constant finding. Thus, in four additional experiments involving cells from separate donors (one of which is shown in Fig. $5 A$ ) monocytes preinfected with $L$. donovani and secondarily stimulated with $S$. aureus had a level of IL- $1 \beta$ mRNA equal to that detected in cells stimulated with $S$. aureus alone. Again, this result was found despite a significant reduction in 
Table III. Comparative Effects of Infection with Leishmania or Treatment with a Soluble Parasite Lysate on Monocyte IL-1.Production

\begin{tabular}{lccc}
\hline & \multicolumn{3}{c}{$\begin{array}{c}\text { IL-1 bioactivity } \\
\text { Experiment No. }\end{array}$} \\
\cline { 2 - 4 } \multicolumn{1}{c}{ Cell treatment } & 1 & 2 & 3 \\
\hline & & $U / m l$ & \\
Nil & ND* & ND & ND \\
Leishmania & ND & ND & ND \\
Lysate & ND & ND & ND \\
S. aureus & $8,690 \pm 1,487^{\ddagger}$ & $5,225 \pm 1,468$ & $1,134 \pm 120$ \\
Leishmania and & & & \\
$\quad$ S. aureus & $3,511 \pm 836^{8}$ & $641 \pm 525^{\S}$ & $535 \pm 76^{\S}$ \\
Lysate and & & & \\
$\quad$ S. aureus & $13,692 \pm 4972$ & $2,830 \pm 666$ & $2,006 \pm 357^{\prime \prime}$ \\
\hline
\end{tabular}

Monolayers of human monocytes were prepared as described in the legend to Fig. 1 using Lab-Tek chamber slides. Cells were either untreated, infected with $L$. donovani at a parasite/cell ratio of 10:1 or treated with a soluble parasite lysate $(10 \mu \mathrm{g} / \mathrm{ml})$ prepared as described in Methods. After $\mathbf{4 h}$ of preincubation under these conditions, cells were either untreated or treated with $S$. aureus and $16 \mathrm{~h}$ later cell-free supernatants were collected and assayed for IL- 1 activity using D10.G4.1 cells.

* ND, not detectable.

¥ Mean \pm SD of triplicate determinations for each experimental group. The differences in IL-1 activities in supernatants of cells treated with Leishmania-S. aureus vs. S. aureus alone were significant at $\leq$ the $1 \%$ level.

"The difference in IL-1 activities in supernatants of cells treated with lysate and $S$. aureus vs. $S$. aureus alone was significant at the $2 \%$ level.

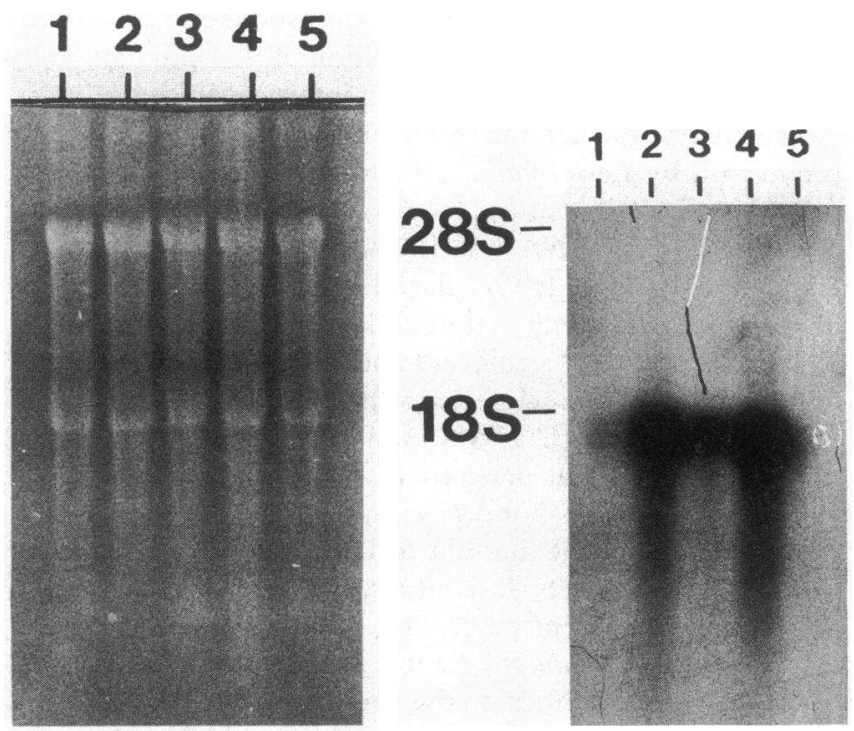

Figure 4. Northern blot analysis of IL-1 $\beta$ mRNA in human monocytes. Monocyte monolayers treated as indicated below were lysed in guanidium isothiocyanate $\sim 12 \mathrm{~h}$ after addition of $S$. aureus or LPS. RNA was isolated and analyzed for IL-1 $\beta$ mRNA (right) as described in the legend to Fig. 2. Lane 1, unstimulated cells; lane 2, LPS (1 $\mu \mathrm{g} / \mathrm{ml}$ ) stimulated cells; lane 3, S. aureus-treated cells; lanes 4 and 5 , cells infected with Leishmania for $4 \mathrm{~h}$ before being stimulated with either LPS (lane 4) or S. aureus (lane 5). (Left) Gel stained with acridine orange.

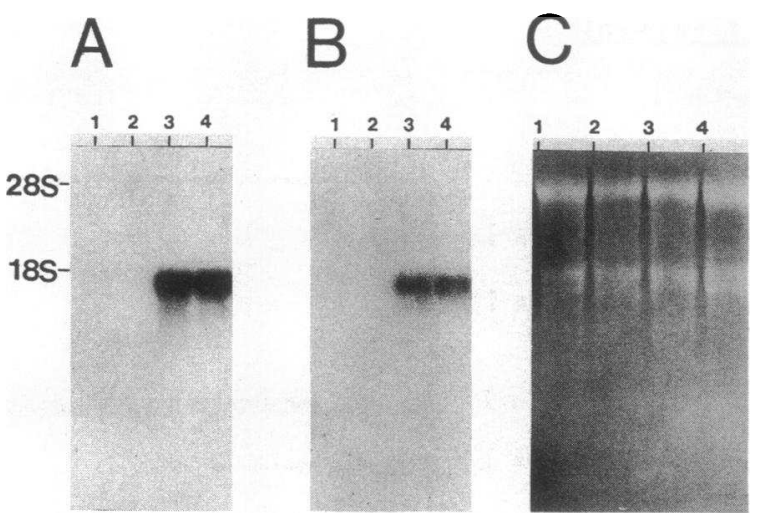

Figure 5. Northern blot analysis of IL-1 $\beta$ and TNF- $\alpha$ mRNA in human monocytes. Monocyte monolayers treated as indicated below were lysed in guanidium isothiocyanate $\sim 12 \mathrm{~h}$ after the addition of $S$. aureus. RNA was isolated and analyzed as described in the legend to Fig. 2. ( $A$ ) IL-1 $\beta$ cDNA probe; $(B)$ TNF- $\alpha$ cDNA probe; $(C)$ ethidium bromide stained gel. Lane 1 , unstimulated monocytes; lane 2 , Leishmania-infected monocytes; lane 3, monocytes stimulated with $S$. aureus; lane 4, cells infected with Leishmania for $4 \mathrm{~h}$ before stimulation with $S$. aureus.

the amount of IL-1 activity detected in the corresponding supernatants. The explanation for the variable effect of Leishmania on IL-1 $\beta$ mRNA levels in these experiments involving secondary stimulation with $S$. aureus is not clear, but may be related to individual donor variability. Nevertheless, taken together the results of these experiments indicated that $(a)$ inhibition of IL-1 production in response to either $S$. aureus or LPS was a constant finding in Leishmania-infected cells, $(b)$ in the case of LPS, decreased IL-1 bioactivity and immunoreactive protein in monocyte supernatants was regularly associated with the normal accummulation of IL- $1 \beta$ mRNA in infected monocytes, and $(c)$ with respect to $S$. aureus the predominant mechanism of inhibition of IL-1 synthesis in Leishmania-infected cells was also postmessage accummulation, but was variably associated with decreased IL- $1 \beta$ mRNA levels as well. Thus, inhibition by Leishmania of the IL-1 response to either $S$. aureus or LPS was likely related predominantly to mechanisms affecting translation of IL- $1 \beta$ mRNA or possibly to stability of translated protein.

Monocyte TNF- $\alpha$ production during infection with $L$. donovani. Infection of freshly isolated human monocytes with Leishmania did not result in the induction of TNF- $\alpha$ production. As shown in Figure 6, supernatants of cells infected with $L$. donovani for $\sim 16 \mathrm{~h}$ had no detectable increase in immunoreactive TNF- $\alpha$ content when compared with control cells. In contrast, stimulation of monocytes with either $S$. aureus or with LPS was associated with significant increases in TNF- $\alpha$ content. Monocyte supernatants were also assayed for TNF- $\alpha$ bioactivity in the L929 cytotoxicity assay. The results (data not shown) indicated that TNF- $\alpha$ bioactivity in monocyte supernatants paralleled exactly the levels of immunoreactive cytokine shown in Fig. 6.

In contrast to the findings with IL-1, monocytes preinfected with Leishmania responded normally to secondary stimuli for the production of TNF- $\alpha$. As shown in Fig. 6, supernatants of cells infected for $4 \mathrm{~h}$ before exposure to either $S$. aureus or LPS had levels of immunoreactive cytokine that were equivalent to those found in supernatants of cells treated 


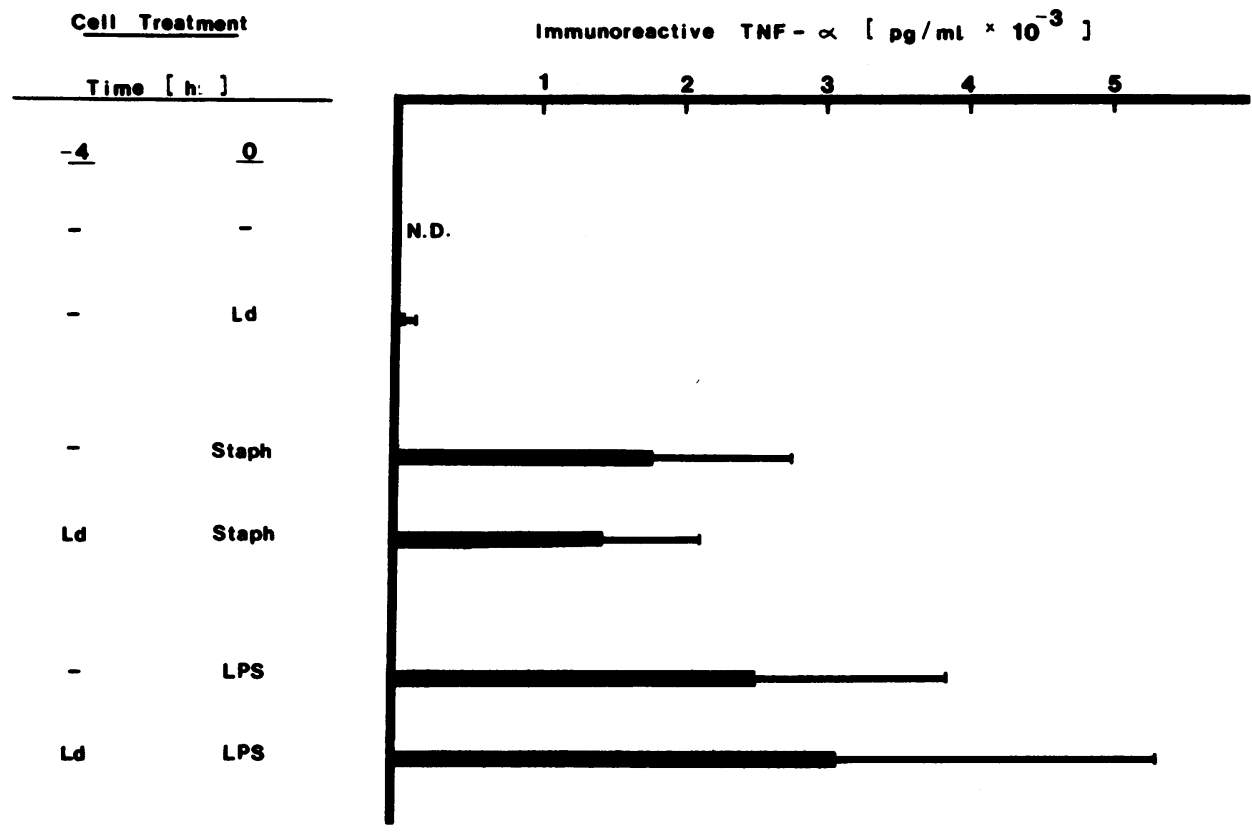

Figure 6. Human monocytes infected with $L$. donovani have normal TNF- $\alpha$ responses to $S$. aureus or LPS. Monolayers were prepared and treated, and supernatants were harvested exactly as described in the legend to Fig. 1. Immunoreactive TNF- $\alpha$ was measured by ELISA. The results shown represent the means $\pm S D$ of values obtained from four identical experiments performed using cells from different donors. ND, not detectable.

with either $S$. aureus or LPS alone. These results were also confirmed by measurements of TNF- $\alpha$ bioactivity in monocyte supernatants (data not shown). Consistent with these observations, was the finding that the steady-state level of TNF- $\alpha$ mRNA in Leishmania-infected, $S$. aureus-treated cells was equivalent to the level of TNF- $\alpha$ mRNA detected in $S$. aureus-induced normal monocytes (Fig. $5 \mathrm{~B}$ ).

Modulation by IFN- $\gamma$ of $L$. donovani effects on monocyte $I L-1$ production. The results of the experiments reported above, indicated that $L$. donovani was capable of infecting human monocytes without eliciting the production of either IL-1 or TNF- $\alpha$. Furthermore, Leishmania infection selectively inhibited monocyte responses to secondary stimuli for cytokine production. Thus, preinfection with Leishmania inhibited monocyte responses to $S$. aureus and to LPS for the production of IL-1, but not for the synthesis of TNF- $\alpha$. Because IFN- $\gamma$ had been shown to upregulate IL-1 synthesis under certain conditions, we asked whether treatment with this cytokine could prevent parasite-induced inhibition of the IL-1 response to a secondary stimulus. As shown in Fig. 7, monocytes

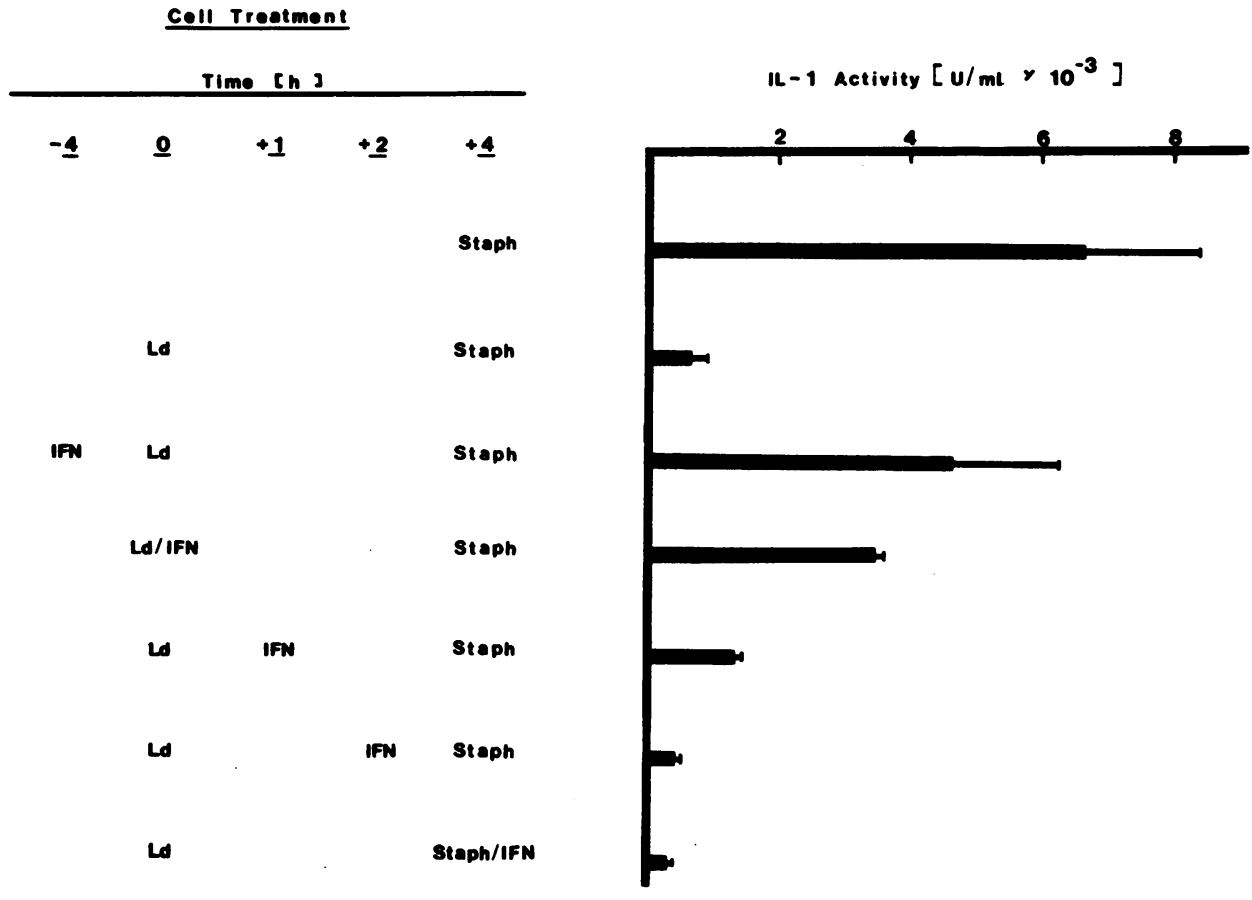

Figure 7. Interferon- $\gamma$ treatment protects monocytes from inhibition of IL-1 production by $L$. donovani. Monolayers were prepared and treated, and supernatants were harvested and assayed as described in the legend to Fig. 1. Where indicated, cells were treated with IFN- $\gamma$ $(200 \mathrm{U} / \mathrm{ml})$ at the designated time points. The results shown are from one of three identical experiments which yielded similar results. The values represent the mean \pm SD of triplicate determinations for each experimental group. The difference between $S$. aureus vs. Leishmania$S$. aureus was significant at the $1 \%$ level. The IL-1 activity detected in the supernatants of cells treated with IFN- $\gamma$ at $-4 \mathrm{~h}$ (followed by Ld at $0 \mathrm{~h}$ ) was not different from the activity in supernatants of cells treated with $S$. aureus alone. The difference in $\mathrm{IL}-1$ activities in supernatants of cells treated simultaneously with IFN- $\gamma$ and Leishmania in comparison to supernatants of cells receiving Leishmania (only) followed by $S$. aureus was significant at the $0.1 \%$ level. Untreated cells, or cells treated with IFN- $\gamma$ alone had no detectable IL-1 activities in their supernatants. 
preinfected with Leishmania for $4 \mathrm{~h}$ were markedly unresponsive to $S$. aureus for the production of IL-1. Treatment of cells with IFN- $\gamma$ for $4 \mathrm{~h}$ before infection, however, abrogated Leishmania-induced inhibition of the IL-1 response to $S$. aureus $(n=6)$. The protective effect of IFN- $\gamma$ was found to be time dependent. Thus, as shown in Fig. 7, significant enhancement of the response to $S$. aureus (by Leishmania-infected cells) was also seen when IFN- $\gamma$ and Leishmania were added simultaneously. On the other hand, when added at progressively later time points (relative to infection) the protective effect of IFN- $\gamma$ was eventually lost.

To examine whether there were conditions under which monocytes would respond to Leishmania alone by producing IL-1, cells were primed with IFN- $\gamma$ before infection. The results shown in Fig. 8 indicate that pretreatment of freshly isolated monocytes with IFN- $\gamma$ could prime cells to respond to Leishmania with the synthesis of IL-1. Supernatants of cells incubated with IFN- $\gamma$ for $4 \mathrm{~h}$ before the addition of Leishmania (for an additional $16 \mathrm{~h}$ ) demonstrated a significant increase in IL-1 content when compared to supernatants of control nonstimulated cells. Treatment of monocytes with IFN- $\gamma$ alone did not result in increased supernatant IL-1 activity in comparison to conditioned medium from unstimulated control cells.

The ability of cytokine treatment to prime cells to respond to Leishmania by producing IL-1 was also time-dependent. As shown in Fig. 8, the simultaneous addition of Leishmania and IFN- $\gamma$ resulted in significantly less priming for IL-1 production when compared to cytokine pretreatment. When leishmania infection was followed either 2 or $4 \mathrm{~h}$ later by the addition of IFN- $\gamma$, the ability to convert cells from being IL-1 nonresponders to IL-1 responders was progressively lost. The priming effect of IFN- $\gamma$ for monocyte IL-1 synthesis in response to Leishmania was found to vary amongst monocyte donors. Thus, significant priming was observed in six out of nine experiments using cells from distinct donors. This variability may be related to heterogeneous responses to IFN- $\gamma$.

IFN- $\gamma$ primes monocytes to produce TNF- $\alpha$ in response to $L$. donovani. As shown in Table IV, monocytes primed with IFN- $\boldsymbol{\gamma}$ produced large amounts of immunoreactive TNF- $\alpha$ in response to infection with Leishmania (priming was observed in three out of five separate experiments using cells from individual donors). Treatment of cells with either IFN- $\gamma$ or Leishmania alone resulted in minimal or negligible amounts of TNF- $\alpha$ production (when compared to unstimulated cells). On the other hand, the content of immunoreactive TNF- $\alpha$ detected in supernatants of cells (from three of five donors) primed with IFN- $\gamma$ for $4 \mathrm{~h}$ before the addition of Leishmania was increased significantly (from 7- to 30-fold) in comparison to supernatants of cells treated with Leishmania alone.

\section{Discussion}

The results of the present study demonstrate that amastigotes of $L$. donovani are capable of infecting human monocytes without stimulating these cells to synthesize IL-1 or to secrete IL-1 activity into their supernatants. This finding is in agreement both with previous experiments from this laboratory which examined the interaction of this organism with murine macrophages (25) and with the data of Crawford et al. (29). The latter workers reported that human monocytes infected with Leishmania major also did not produce IL-1. On the other hand, these findings are in direct contrast to those recently reported by Cillari and co-workers demonstrating that murine macrophages responded to infection with $L$. major by producing IL-1 (30). The explanation for the divergent findings of these two studies that examined $L$. major is not known. The potential difference, however, between $L$. donovani and $L$.

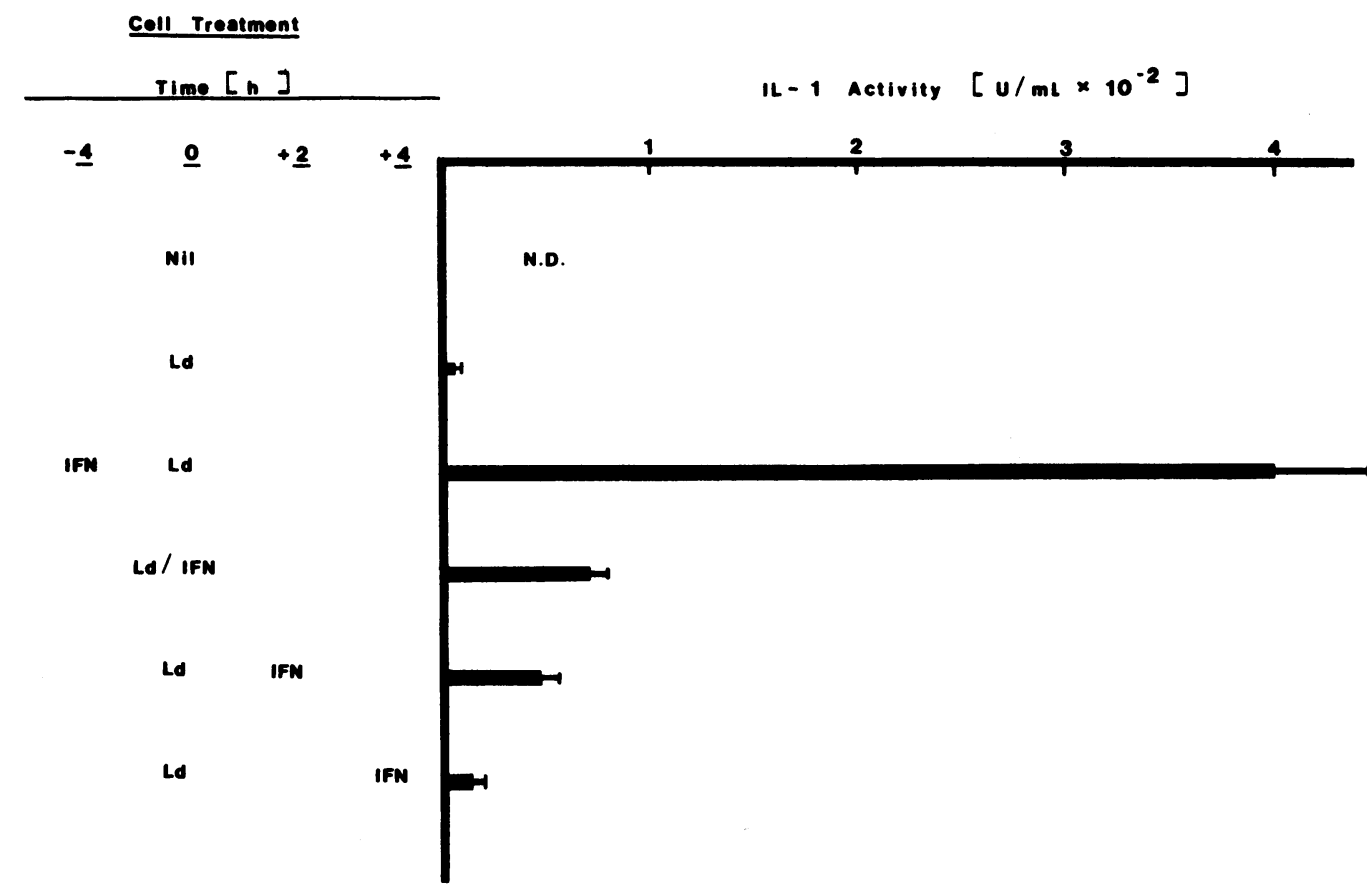

Figure 8. Interferon- $\gamma$ treatment primes monocytes to respond to $L$. donovani with the production of IL-1. The details of cell preparation, infection with Leishmania and IL-1 assay were as described in the legend to Fig. I. IFN- $\gamma$ was used at $200 \mathrm{U} / \mathrm{ml}$. The results shown are from one of nine identical experiments, six of which yielded similar results, and represent the mean \pm SD of triplicate determinations for each group. The differences found when comparing IL-1 activities in supernatants of cells treated with Leishmania alone in comparison to supernatants of cells treated with Leishmania and with IFN- $\gamma$ at either $-4 \mathrm{~h}, 0 \mathrm{~h}$, or $+2 \mathrm{~h}$ were all significant at the $2 \%$ level or less. Supernatants of cells treated with IFN- $\gamma$ alone had no detectable IL-1 bioactivity. 
Table IV. IFN- $\gamma$ Primes Human Monocytes to Produce TNF- $\alpha$ in Response to L. donovani

\begin{tabular}{|c|c|c|c|c|c|}
\hline \multirow[b]{2}{*}{ Cell treatment } & \multicolumn{5}{|c|}{$\begin{array}{l}\text { Immunoreactive TNF- } \alpha \\
\text { Experiment No. }\end{array}$} \\
\hline & 1 & 2 & 3 & 4 & 5 \\
\hline & \multicolumn{5}{|c|}{$p g / m l$} \\
\hline Nil & $<50$ & $<50$ & $<50$ & 142 & 659 \\
\hline L. donovani & 145 & 210 & 335 & 132 & 221 \\
\hline IFN- $\gamma^{*}$ & 36 & 670 & $<50$ & 240 & 131 \\
\hline IFN- $\gamma+L$. donovani ${ }^{\ddagger}$ & 2,070 & 6,400 & 2,500 & 147 & 526 \\
\hline
\end{tabular}

Monolayers of human monocytes, prepared as described in the legend to Fig. 1, were either untreated or infected with $L$. donovani at a parasite/cell ratio of 10:1. Supernatants were removed after $16 \mathrm{~h}$ of culture and analyzed for immunoreactive TNF- $\alpha$ by ELISA. For the five experiments shown the infection rate was $88.9 \pm 7.8 \%$ (mean $\pm \mathrm{SD}$ ) with a mean of $8.1 \pm 2.9$ amastigotes per cell.

* IFN- $\gamma$ was used at $200 \mathrm{U} / \mathrm{ml}$.

¥ Monolayers treated with both IFN- $\gamma$ and $L$. donovani were incubated with lymphokine for $4 \mathrm{~h}$ before infection. The values for immunoreactive TNF- $\alpha$ in supernatants of cells treated with $L$. donovani alone and those detected in supernatants of cells treated with IFN- $\gamma+L$. donovani were $\log$ transformed and compared by Student's paired $t$ test (two-tailed). The mean increase in TNF- $\alpha$ content associated with IFN- $\gamma$ pretreatment was significant at $P=0.04$.

major with respect to the production of IL-1 by infected mononuclear cells may be related to fundamental differences in the immunobiology of infection with these two species of Leishmania.

The data presented above furthermore establish that cellular unresponsiveness to Leishmania donovani with respect to IL- 1 synthesis is related to the absence of IL- $1 \beta$ mRNA accummulation following monocyte infection (Fig. 2). This finding is consistent with and provides an explanation for our prior inability to detect either intracellular, membrane or secreted IL-1 activities associated with leishmania-infected murine macrophages (25).

The data presented herein also indicate that in addition to infecting human monocytes without inducing IL-1 production, $L$. donovani is capable of inhibiting monocyte IL-1 responses to other stimuli. Inhibition by Leishmania of the IL-1 response to either $S$. aureus or LPS was likely related predominantly to mechanisms affecting translation of IL- $1 \beta$ mRNA or possibly to stability of translated protein. This conclusion is supported by several findings including $(a)$ normal steady-state levels of either $S$. aureus (Fig. 5) or LPS-induced (Fig. 4) IL-1 $\beta$ mRNA in Leishmania-preinfected cells, $(b)$ decreased supernatant content of IL-1 was not explained by altered kinetics of IL-1 release induced by infection (Fig. 3), and (c) the absence of the intracellular accummulation of IL-1 in infected cells (Table II). Although the predominant mechanism of inhibition of $S$. aureus-induced IL-1 synthesis in Leishmania-infected cells was post-IL-1 $\beta$ message accumulation, these particular experimental conditions were variably associated with decreased steady-state IL- $1 \beta$ mRNA levels as well $(n=2$ out of 6 experiments). The finding of diminished steady-state IL- $1 \beta$ mRNA levels under these conditions may have been related to either decreased gene transcription or accelerated mRNA degradation. The observation that $L$. donovani inhibited IL-1 syn- thesis at different levels along the induction pathway, according to the secondary stimulus involved (i.e., S. aureus vs. LPS) is consistent with previous studies in which stimulus-specific regulation of IL-1 production by mononuclear phagocytes was shown. For instance, Kunkel et al. (31) found IL-1 production by murine macrophages to be differentially regulated according to whether the inducing stimulus used was phagocytic or soluble. Furthermore, Fenton and co-workers (32) demonstrated that independent mechanisms regulated phorbol ester vs. LPS induction of IL-1 production by THP-1 cells, by human monocytes and by the HL-60 myelocytic cell line.

Inhibition of monocyte IL-1 production by Leishmania both at the level of mRNA accummulation (in response to $S$. aureus) as well as posttranscriptionally (in response to LPS or $S$. aureus), is also consistent with data demonstrating that IL-1 expression is subject to regulatory control at each of these levels. Thus, glucocorticoids have been shown to suppress IL- $1 \beta$ gene transcription and mRNA accummulation in cells of the promonocyte cell line U937 $(33,34)$. Lew and coworkers also reported suppression of LPS-induced IL- $1 \alpha$ and IL- $1 \beta$ mRNA accummulation in adherent human monocytes treated with prednisolone (35), although Kern et al. noted only post-transcriptional suppression of IL-1 production in dexamethasone treated human monocytes in suspension culture (36). Furthermore, both glucocorticoids $(33,36)$ and elevated levels of prostaglandins (34) have been shown to downregulate IL-1 expression posttranscriptionally through a cAMP-dependent pathway $(34,37)$. In regard to the latter, we have previously shown that macrophages respond to infection with $L$. donovani with increased synthesis of prostaglandin $\mathrm{E}_{2}(38)$ and such a mechanism could explain a predominantly posttranscriptional suppression of the IL-1 response to either LPS or $S$. aureus in Leishmania-infected cells. Attempts to demonstrate such a relationship by treating cells with cyclooxygenase inhibitors such as indomethacin or sodium meclofenamate prior to and during Leishmania infection, did not result in the restoration the IL-1 response to LPS (data not shown). A negative result from such an experiment does not, however, provide definitive evidence to exclude a role for prostaglandins. Thus, as has been shown by us $(38)$ and by others $(39,40)$ these putative cyclooxygenase inhibitors lack specificity in that they also inhibit the metabolism of arachidonic acid via the lipoxygenase pathway. This consideration is of particular importance since evidence has been presented to indicate that lipoxygenase products of arachidonic acid promote monocyte IL-1 synthesis $(41,42)$. The failure of putatively specific cyclooxygenase inhibitors to restore the IL-1 response to LPS in Leishmania-preinfected cells could thus be related to countervailing effects of inhibitors on these dual pathways of arachidonic acid oxygenation.

As was the case for IL-1, the results of the present study furthermore indicate that infection of human monocytes with $L$. donovani did not result in increased TNF- $\alpha$ activity in monocyte supernatants. This result may be interpretated to indicate that Leishmania did not induce cytokine synthesis, since $>90 \%$ of TNF- $\alpha$ produced by fresh monocytes is found extracellularly (16). This interpretation is supported by the finding that TNF- $\alpha$ mRNA accummulation was not induced in monocytes in response to Leishmania alone (Fig. 5).

These findings demonstrate, therefore, that neither IL-1 nor TNF- $\alpha$ are produced by human monocytes in response to Leishmania. Of particular interest, however, was the observa- 
tion that these two cytokines were not coordinately regulated during infection with Leishmania. Thus, in response to secondary stimuli the production of IL-1 was found to be inhibited in leishmania infected cells, but the production of TNF- $\alpha$ was unaffected. This selective inhibitory effect of Leishmania on the production of these two cytokines is consistent with the findings of Burchett et al., indicating that the synthesis of IL-1 and TNF- $\alpha$ in human monocytes are not coordinately regulated (16).

The finding that human monocytes were unresponsiveness to Leishmania with respect to cytokine production, and that infection inhibited IL-1 induction in response to secondary stimuli, prompted examination of whether these events could be modified by IFN- $\gamma$. This approach was based upon data demonstrating the capacity of this lymphokine to upregulate IL-1 production by both freshly isolated human monocytes and by in vitro monocyte-derived macrophages (16-19). Treatment of cells with IFN- $\gamma$ before infection, primed cells to respond to $L$. donovani by producing both IL- 1 ( $n=6$ out of 9 experiments) and TNF- $\alpha$ ( $n=3$ out of 5 experiments). Compared to cells that were not treated with lymphokine, the priming effect of IFN- $\gamma$ was greater (in absolute, but not relative terms) for monocyte production of TNF- $\alpha$ (in response to Leishmania) than it was for the synthesis of IL-1 (compare Fig. 8 and Table IV). This result is in agreement with previous results (16) indicating a quantitatively greater priming effect of IFN- $\gamma$ on monocyte production of TNF- $\alpha$ in comparison to IL-1.

In addition to converting cells from a nonresponsive state to a responsive one, with respect to cytokine production upon exposure to Leishmania, IFN- $\gamma$ was also able to abrogate parasite-induced inhibition of the IL-1 response to a second stimulus (Fig. 7). Both in the case of priming for cytokine production (Fig. 8) and also in preventing inhibition of the IL-1 response (Fig. 7), the efficacy of lymphokine treatment was time dependent. Treatment with IFN- $\gamma$ before exposure to Leishmania was required for maximal responses. When lymphokine treatment was initiated as little as $2 \mathrm{~h}$ after leishmania infection efficacy was lost.

Although the exact mechanism(s) whereby IFN- $\gamma$ modulated monocyte IL-1 and TNF- $\alpha$ responses to Leishmania are as yet unknown, this lymphokine has been shown to increase the duration of transcription of the genes encoding these cytokines when cells were activated by LPS (16). Enhancement by IFN- $\gamma$ of cytokine mRNA stabilities were also described (16). In addition, priming of cells by IFN- $\gamma$ for increased IL- 1 responses to various stimuli may be related to modulation of monocyte arachidonic acid metabolism by this lymphokine. Prostaglandins of the E series inhibit monocyte IL-1 production $(31,37)$ and IFN- $\gamma$ has been shown to downregulate monocyte $\mathrm{PGE}_{2}$ synthesis in response to a variety of agonists (43-46). Modulation by IFN- $\gamma$ of monocyte $\mathrm{PGE}_{2}$ production in response to Leishmania, therefore, could potentially explain its capacity to upregulate cytokine production during in vitro infection.

Data from both the present and from previous experiments (25) clearly show that the direct interaction of $L$. donovani with mononuclear phagocytes does not result in the production of IL-1. In addition, here we present evidence that TNF- $\alpha$ is also not produced under these conditions. Considering that IL-1 and TNF- $\alpha$ represent two of the three (interferon- $\alpha$ being the third) currently recognized endogenous pyrogens (47), these data must be viewed in light of the fact that fever is nearly a constant feature in patients with visceral leishmaniasis (13, 14). At least two explanations may account for this apparent paradox. First, patients with visceral leishmaniasis have been found to have circulating immune complexes $(48,49)$ and the latter have been shown to induce monocyte IL-1 production $(29,50)$. Secondly, it has recently been reported $(51)$ that splenic macrophages obtained from Syrian hamsters infected with $L$. donovani, when cultured in vitro, produce increased amounts of IL- 1 and TNF- $\alpha$. In light of the findings of the present study, it is reasonable to postulate that the production of IFN- $\gamma$ locally within the spleen may prime tissue macrophages to produce TNF- $\alpha$ or IL-1 or both in response to Leishmania.

Previously, we reported that $L$. donovani inhibited the accummulation of MHC class II mRNA in infected macrophages in response to IFN- $\gamma$ (52). Recent data indicates that this effect is related to decreased transcription of MHC class II genes (P. Kwan, W. R. McMaster, W. Ng, and N. Reiner, manuscript in preparation). These observations, together with the finding of selective, post-transcriptional inhibition by Leishmania of stimulus-induced IL-1 production, raise questions regarding the effects of intracellular parasitism on mRNA translation, the stabilities of translated proteins and the integrity of signal transduction mechanisms in mononuclear phagocytes. Studies which are now underway are directed at examining these questions including defects in intracellular signalling which may contribute to abnormal responses observed in infected cells.

When considered in the context of accruing data, the findings of the present study may be of fundamental importance to the immunobiology of leishmania infections. Thus, based upon the ability of IFN- $\gamma$ to promote mononuclear phagocyte killing of Leishmania and a variety of other intracellular pathogens, clinical trials of immunotherapy with recombinant IFN- $\gamma$ in human visceral leishmaniasis were recently undertaken. Results of these studies indicated that this lymphokine was of therapeutic benefit in this disease (20). The mechanism accounting for the efficacy of IFN- $\gamma$ in this setting may have been related to the direct induction of monocyte killing of Leishmania. On the other hand, the findings of the present study, that IFN- $\gamma$ primes monocytes to produce both TNF- $\alpha$ and IL-1 in response to Leishmania, suggest a potential alternative mechanism by which IFN- $\gamma$ may mediate its therapeutic effect. Thus, both IL-1 and TNF- $\alpha$ have been shown to mediate antimicrobial effects against intracellular pathogens (3, 9-12). Moreover, and of direct relevance to the results of the present study, are the recent findings of Titus and coworkers that demonstrated a protective role for TNF- $\alpha$ in experimental leishmaniasis (15). This suggests the possibility that priming by IFN- $\gamma$ for monocyte TNF- $\alpha$ production (and perhaps IL-1) in response to Leishmania is a potential mechanism by which IFN- $\gamma$ mediates its therapeutic effect in vivo. Although direct evidence that IL-1 plays a role in the pathogenesis of leishmania infections has not yet been presented, it is reasonable to consider this a likely possibility given the considerable extent to which the biological activities of IL-1 and TNF overlap (4-8). Furthermore, the ability of IFN- $\gamma$ to promote monocyte IL-1 production in response to Leishmania may have other indirect effects on the immune response. Thus, numerous investigators have demonstrated cellular immune defects and deficiencies of lymphokine production in visceral 
leishmaniasis $(21,53-55)$. The precise relationship of these immune deficiencies to inhibition of IL-1 production (which plays a central role in the evolution of a cellular immune response) by Leishmania remains to be defined. Nevertheless, the ability of mononuclear phagocytes primed in vivo with IFN- $\gamma$ to respond to Leishmania by producing IL-1 could potentially reverse some of these immune defects. Such an effect would favor the evolution of a protective, antileishmanial cell-mediated immune response, which is critical to ultimate cure $(13,14)$.

\section{Acknowledgments}

We thank Drs. Steven Gillis and Kenneth H. Grabstein of Immunex Corp., Seattle, WA, and Drs. H. Michael Shepard, Patrick W. Gray, and Dianne Pennica of Genentech Inc., South San Francisco, CA, for providing reagents and probes. We are also grateful to Dr. Noel Buskard, Ms. June Humphreys, and the staff of the British Columbia and Yukon Division of the Canadian Red Cross for providing cells.

This work was supported by grants MA-8633 and MT-7399 from the Medical Research Council of Canada, grants 47(87-1) and 125(872) from the British Columbia Health Care Research Foundation, and by grants HD-18184, AI-00658 and HD-07233 from the National Institutes of Health. Dr. Reiner is the recipient of a Research Scholarship Award from the British Columbia Health Care Research Foundation.

\section{References}

1. Unanue, E. R., and P. M. Allen. 1987. The basis for the immunoregulatory role of macrophages and other accessory cells. Science (Wash. DC). 236:551-557.

2. Nathan, C. F. 1987. Secretory products of macrophages. J. Clin. Invest. 79:319-326.

3. Murray, H. W. 1988. Interferon- $\gamma$, the activated macrophage, and host defense against microbial challenge. Ann. Intern. Med. 108:595-608.

4. Dinarello, C. A. 1984. Interleukin-1. Rev. Infect. Dis. 6:51-95.

5. Durum, S. K., J. A. Schmidt, and J. J. Oppenheim. 1985. Interleukin 1: an immunological perspective. Annu. Rev. Immunol. 3:26387.

6. Oppenheim, J. J., E. J. Kovacs, K. Matsushima, and S. K. Durum. 1986. There is more than one interleukin 1. Immunol. Today. 7:45-56.

7. Dinarello, C. A. 1988. Biology of interleukin 1. FASEB (Fed. Am. Soc. Exp. Biol.) J. 2:108-115.

8. Beutler, B., and A. Cerami. 1986. Cachectin and tumour necrosis factor as two sides of the same biological coin. Nature (Lond.). 320:583-588.

9. De Titto, E. H., J. R. Catterall, and J. S. Remington. 1986. Activity of recombinant tumor necrosis factor on Toxoplasma gondii and Trypanosoma cruzi. J. Immunol. 137:1342-1345.

10. Czuprynski, C. J., J. F. Brown, K. M. Young, A. J. Cooley, and R. S. Kurtz. 1988. Effects of murine recombinant interleukin $1 \alpha$ on the host response to bacterial infection. J. Immunol. 140:962-968.

11. Bermudez, L. E. M., and L. S. Young. 1988. Tumor necrosis factor alone or in combination with IL-2, but not interferon- $\gamma$, is associated with macrophage killing of Mycobacterium avium complex. J. Immunol. 140:3006-3013.

12. Ozaki, Y., T. Ohashi, A. Minami, and S.-I. Nakamura. 1987. Enhanced resistance of mice to bacterial infection induced by recombinant human IL 1- $\alpha$. Infect. Immun. 55:1s436-1440.

13. Wyler, D. J., and P. D. Marsden. 1983. Leishmaniasis. In Tropical and Geographical Medicine. K. S. Warren, A. A. F. Mahmoud, editors. McGraw-Hill Book Co., Inc. New York. 270-280.

14. Pearson, R. D., D. A. Wheeler, L. H. Harrison, and H. D. Kay.
1984. The immunobiology of leishmaniasis. Rev. Infect. Dis. 5:907927.

15. Titus, R. G., B. Sherry, and A. Cerami. 1989. Tumor necrosis factor plays a protective role in experimental murine cutaneous leishmaniasis. J. Exp. Med. 170:2097-2104.

16. Burchett, S. K., W. M. Weaver, J. A. Westall, A. Larsen, S. Kronheim, and C. B. Wilson. 1988. Regulation of tumor necrosis factor/cachectin and IL-1 secretion in human mononuclear phagocytes. J. Immunol. 140:3473-3481.

17. Gerrard, T. L., J. P. Siegel, D. R. Dyer, and K. C. Zoon. 1987. Differential effects of interferon- $\alpha$ and interferon- $\gamma$ on interleukin 1 secretion by monocytes. J. Immunol. 138:2535-2540.

18. Arenzana-Seisdedos, F., J. L. Virelizier, and W. Fiers. 1985. Interferons as macrophage-activating factors. III. Preferential effects of interferon- $\gamma$ on the interleukin 1 secretory potential of fresh or aged human monocytes. J. Immunol. 134:2444-2448.

19. Haq, A. U., J. J. Rinehart, and R. D. Maca. 1985. The effect of gamma interferon on IL-1 secretion of in vitro differentiated human macrophages. J. Leukocyte Biol. 38:735-746.

20. Badaro, R., E. Falcoff, F. S. Badaro, E. M. Carvalho, D. Pedral-Sampaio, A. Barral, J. S. Carvalho, M. Barral-Netto, M. Brandley, L. Silva, J. C. Bina, R. Teixeira, R. Falcoff, H. Rocha, J. L. Ho, and W. D. Johnson. 1990. Treatment of visceral leishmaniasis with pentavalent antimony and interferon gamma. $N$. Engl. J. Med. 322:16-21.

21. Reiner, N. E. 1982. Host-parasite relationship in murine leishmaniasis: pathophysiological and immunological changes. Infect. Immun. 38:1223-1230.

22. Gray, P. W., D. Glaister, E. Chen, D. V. Goeddel, and D. Pennica. 1986. Two interleukin 1 genes in the mouse: cloning and expression of the cDNA for murine IL $1 \beta$. J. Immunol. 137:36443648.

23. Pennica, D., G. E. Nedwin, J. S. Hayflick, P. H. Seeburg, R. Derynck, M. A. Palladino, W. J. Kohr, B. B. Aggarwal, and D. V. Goeddel. 1984. Human tumor necrosis factor: precursor structure, expression and homology to lymphotoxin. Nature (Lond.). 312:724729.

24. Kaye, J. S., S. Gillis, S. B. Mizel, E. M. Shevach, T. R. Malek, C. A. Dinarello, L. B. Lachmann, and C. A. Janeway. 1984. Growth of a cloned helper T-cell line induced by a monoclonal antibody specific for the antigen receptor: interleukin 1 is required for the expression of receptors for interleukin 2. J. Immunol. 133:1339-1345.

25. Reiner, N. E. 1987. Parasite accessory cell interactions in murine leishmaniasis 1. Evasion and stimulus-dependent suppression of the macrophage interleukin 1 response by Leishmania donovani. $J$. Immunol. 138:1919-1925.

26. Chirgwin, J. M., A. E. Przybyla, R. J. McDonald, and W. J. Rutter. 1979. Isolation of biologically active ribonucleic acid from sources enriched in ribonucleases. Biochemistry. 18:5294-5299.

27. Lerach, H., D. Diamond, J. M. Wozney, and H. Boedtker. 1977. RNA molecular weight determinations by gel electrophonesis under denaturing conditions: a critical re-examination. Biochemistry. 16:4743-4751.

28. Feinberg, A. P., and B. Vogelstein. 1983. A technique for radiolabelling DNA restriction endonuclease fragments to high specific activity. Anal. Biochem. 132:613.

29. Crawford, G. D., D. J. Wyler, and C. A. Dinarello. 1985. Parasite-monocyte interactions in human leishmaniasis: production of interleukin-1 in vitro. J. Infect. Dis. 152:315-322.

30. Cillari, E., M. Dieli, E. Maltese, S. Milano, A. Salerno, and F. Y. Liew. 1989. Enhancement of macrophage IL-1 production by Leishmania major infection in vitro and its inhibition by IFN- $\gamma$. $J$. Immunol. 143:2001-2005.

31. Kunkel, S. L., S. W. Chensue, and S. H. Phan. 1986. Prostaglandins as endogenous mediators of interleukin 1 production. J. Immunol. 136:186-192.

32. Fenton, M. J., M. W. Vermeulen, B. D. Clark, A. C. Webb, and P. E. Auron. Human pro-IL-1 $\beta$ gene expression in monocytic cells is regulated by two distinct pathways. J. Immunol. 140:2267-2273. 
33. Lee, S. L., A. P. Tsou, H. Chan, J. Thomas, K. Petrie, E. M. Eugui, and A. C. Allison. 1988. Glucocorticoids selectively inhibit the transcription of the interleukin $1 \beta$ gene and decrease the stability of interleukin $1 \beta$ mRNA. Proc. Natl. Acad. Sci. USA. 85:1204-1208.

34. Knudsen, P. J., C. A. Dinarello, and T. B. Strom. 1987. Glucocorticoids inhibit transcriptional and post-transcriptional expression of interleukin 1 in U937 cells. J. Immunol. 139:4129-4134.

35. Lew, L., J. J. Oppenheim, and K. Matsushima. 1988. Analysis of the suppression of IL- $1 \alpha$ and IL- $1 \beta$ production in human peripheral blood mononuclear adherent cells by a glucocorticoid hormone. $J$. Immunol. 140:1895-1902.

36. Kern, J. A., R. L. Lamb, J. C. Reed, R. P. Daniele, and P. C. Nowell. 1988. Dexamethasone inhibition of interleukin 1 beta production by human monocytes. J. Clin. Invest. 81:237-244.

37. Knudsen, P. J., C. A. Dinarello, and T. B. Strom. 1986. Prostaglandins post-transcriptionally inhibit monocyte expression of interleukin 1 activity by increasing intracellular cyclic adenosine monophosphate. J. Immunol. 137:3189-3194.

38. Reiner, N. E., and C. J. Malemud. 1985. Arachidonic acid metabolism by Leishmania donovani infected murine peritonal macrophages: in vitro evidence for parasite-induced alterations in cyclooxygenase and lipoxygenase pathways. J. Immunol. 134:556-563.

39. Paajanen, H., J. Mannisto, and P. Utoila. 1982. Aspirin inhibits arachidonic acid metabolism via lipoxygenase and cyclooxygenase in hamster isolated lungs. Prostaglandins. 23:731-.

40. Myers, R. F., and M. I. Siegel. 1983. Differential effects of anti-inflammatory drugs on lipoxygenase and cyclooxygenase activities of neutrophils from a reverse passive arthus reaction. Biochem. Biophys. Res. Commun. 112:586-.

41. Dinarello, C. A., I. Bishai, L. J. Rosenwasser, and F. Coceani. 1984. The influence of lipoxygenase inhibitors on the in vitro production of human leukocytic pyrogen and lymphocyte activating factor (interleukin-1). J. Immunopharmacol. 6:43-50.

42. Rola-Pleszczynski, M., and I. Lemaire. 1985. Leukotrienes augment interleukin 1 production by human monocytes. J. Immunol. 135:3958-3961.

43. Russell, S. W., and J. L. Pace. 1984. $\gamma$-interferon interferes with the negative regulation of macrophage activation by prostaglandin $\mathrm{E}$. Mol. Immunol. 21:249-254.

44. Boraschi, D., S. Censini, and A. Tagliabue. 1984. Interferon- $\gamma$ reduces macrophage-suppressive activity by inhibiting prostaglandin
$E_{2}$ release and inducing interleukin 1 production. J. Immunol. 133:764-767.

45. Boraschi, D., S. Censini, M. Bartalini, and A. Tagliabue. 1985. Regulation of arachidonic acid metabolism in macrophages by immune and nonimmune interferons. J. Immunol. 135:502-505.

46. Browning, J. L., and A. Ribolini. 1987. Interferon blocks interleukin 1-induced prostaglandin release from human peripheral monocytes. J. Immunol. 138:2857-2863.

47. Dinarello, C. A., J. G. Cannon, S. M. Wolf, H. A. Bernheim, B. Beutler, A. Cerami, I. S. Figari, M. A. Palladino, Jr., and J. V. O'Connor. 1986. Tumor necrosis factor (cachectin) is an endogenous pyrogen and induces production of interleukin 1. J. Exp. Med. 163:14331450.

48. Carvalho, E. M., B. S. Andrews, R. Martinelli, M. Dutra, and M. Rusha. 1983. Circulating immune complexes and rheumatoid factor in schistosomiasis and visceral leishmaniasis. Am. J. Trop. Med. Hyg. 32:61-68.

49. Pearson, R. D., J. E. Alencar, R. Romito, T. G. Naidu, A. C. Young, and J. S. Davis. 1983. IV. Circulating immune complexes and rheumatoid factors in visceral leishmaniasis. J. Infect. Dis. 147:1102.

50. Arend, W. P., F. G. Joslin, and R. J. Massoni. 1985. Effects of immune complexes on production by human monocytes of interleukin 1 or an interleukin 1 inhibitor. J. Immunol. 134:3868-3875.

51. Pearson, R. D., T. Evans, D. Smith, D. Wiedel, K. Mason, and J. Castracane. 1988. Wasting and macrophage production of interleukin 1 and tumor necrosis factor/cachectin in visceral leishmaniasis. Clin. Res. 36:466A. (Abstr.)

52. Reiner, N. E., W. Ng, T. Ma, and W. R. McMaster. 1988. Kinetics of IFN- $\gamma$ binding and MHC class II mRNA levels in leishmania-infected macrophages. Proc. Natl. Acad. Sci. USA. 85:43304334.

53. Murray, H. W., H. Masur, and J. S. Keithly. 1982. Cell-mediated immune response in experimental visceral leishmaniasis. I. Correlation between resistance to Leishmania donovani and lymphokine-generating capacity. J. Immunol. 131:1487-1491.

54. Reiner, N. E., and J. H. Finke. 1983. Interleukin 2 deficiency in murine leishmaniasis donovani and its relationship to depressed spleen cell responses to phytohemagglutinin. J. Immunol. 131:1487-1491.

55. Carvalho, E. M., R. Badaro, S. G. Reed, T. C. Jones, and W. D. Johnson, Jr. 1985. Absence of gamma interferon and interleukin 2 production during active visceral leishmaniasis. J. Clin. Invest. 76:2066-2069. 